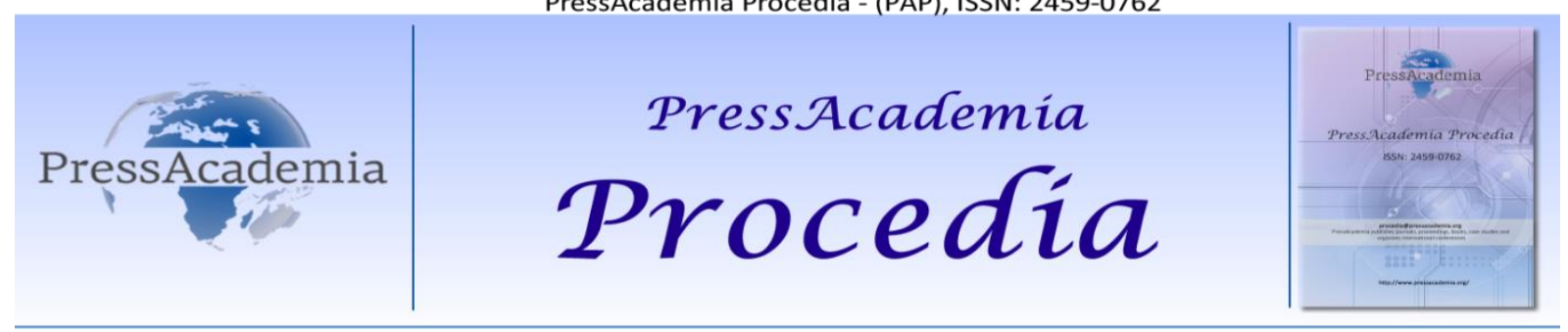

Global Business Research Congress (GBRC), May 24-25, 2017, Istanbul, Turkey.

\title{
ISSUES CONCERNING LIABILITY RISING FROM PUBLIC RECEIVABLES IN CASE OF SHARE TRANSFER
}

\author{
DOI: 10.17261/Pressacademia.2017.424 \\ PAP-GBRC-V.3-2017(39)-p.385-391
}

\section{Mahmut Kabakcı}

Istanbul Technical University, MAcka Campus,34367 Beşiktaş, Istanbul, Turkey. mahmutkabakci@yahoo.com

To cite this document

KabakcI, M. (2017). Issues concerning liability rising from public receivables in case of share transfer. PressAcademia Procedia (PAP), V.3, p.385-391.

Permemant link to this document: http://doi.org/10.17261/Pressacademia.2017.424

Copyright: Published by PressAcademia and limited licenced re-use rights only.

\begin{abstract}
On 20/04/2016, the Law No. 6701 on Human Rights and Equality Institution of Turkey entered into force. Although it seems like a law of Partners of corporations, in principle, are not personally liable for debt of corporations provided that they paid the capital they had undertaken. However, there were some exceptions to this principle regarding public receivables, notably, tax and social security contributions. One of these exceptions is article 35 of Law numbered 6183 . According to this, partners of limited company are liable pro rata for the public receivables that are uncollectible wholly or partially or seemingly uncollectible and in case of share transfer, transferor and transferee are jointly liable for the public receivables that are due before the date of transfer. Similarly, article 89 of Law numbered 5510 states that in cases of workplace is either taken over or transferred along with the assets and liabilities, or joined or merged with another workplace, new employer is jointly and severally liable for the debts of corporations consisting of contributions, default penalty, default interest and others as well as former employer. In both circumstances, agreements eliminating joint liability of parties for public receivables are void for the creditor Institution, provisions in such agreements determinate recourse. For this reason, there has been significant legal disputes in practice in mergers by share transfer or acquisitions regarding transferee has to bear the public debts that are due before the date of transfer. In this study, recourse between transferee and transferor as being jointly liable will be examined.
\end{abstract}

Keywords: Public receivable, joint liability, recourse, share transfer, social insurance contributions.

JEL Codes: K30, K31

\section{HISSE DEVRI HALINDE KAMU ALACAKLARINDAN DOĞAN SORUMLULUĞA ILIŞKIN SORUNLAR}

\section{ÖZET}

Sermaye şirketlerinde ortaklar, taahhüt ettikleri sermayeyi ödemiş olmaları şartıyla ilke olarak şirket borçlarından şahsen sorumlu değillerdir. Ancak bu esasa, başta vergi ve sosyal sigorta primleri gelmek üzere kamu alacakları bakımından bazı istisnalar getirilmiştir. Bunlardan biri, 6183 sayılı Kanun 35. maddesidir. Buna göre, limited şirket ortakları, şirketten tamamen veya kısmen tahsil edilemeyen veya tahsil edilemeyeceği anlaşılan amme alacağından sermaye hisseleri oranında sorumlu olup, ortağın şirketteki sermaye payını devretmesi halinde, payı devreden ve devralan şahıslar devir öncesine ait kamu alacaklarının ödenmesinden müteselsilen sorumlu tutulur. Benzer şekilde 5510 sayılı Kanunun 89. maddesi, işyeri aktif veya pasifi ile birlikte devralınır veya intikal ederse ya da başka bir işyerine katılır veya birleşirse eski işverenin Kuruma olan prim ile gecikme cezası, gecikme zammı ve diğer ferilerinden oluşan borçlarından, aynı zamanda yeni işveren de müştereken ve müteselsilen sorumludur hükmünü amirdir. Her iki halde de, tarafların kamu borçlarından müteselsil sorumluluğu ortadan kaldırıcı kararlaştırmada bulunmaları, alacaklı Kuruma karşı geçersizdir, bu şekilde bir sözleşme hükmü aralarındaki rücu ilişkisini belirler. Bu nedenle uygulamada hisse devri ya da devralma şeklinde gerçekleşen şirket birleşmelerinde, devir öncesi döneme ait kamu borçlarını devralanın ödemek zorunda kalması, önemli uyuşmazlıklara neden olmaktadır. Bu çalışmada müteselsil borçlular olarak devreden ve devralanlar arasındaki rücu konusu incelenecektir.

Anahtar Kelimeler: Amme alacağı, müteselsil sorumluluk, rücu, hisse devri, sosyal sigorta primleri JEL Kodları: K30, K31 


\section{Gíiş̧}

Ticaret hukukunda sermaye şirketlerinin ortaklarının şirketin borçlarından şahsen sorumlu olmamaları asıldır (Bilgili, Demirkapı:2013, 62). Bu sorumsuzluk ilkesi, ortağın taahhüt ettiği sermayeyi ödemiş olması şartına bağılır. Ortak taahhüt ettiği sermayeyi peşin ya da yasadaki azami süresinde ödediği durumda, şirketin ticari faaliyetlerinden kaynaklanan borçlarını ödeyemediğinde, acze düştüğünde alacaklılar ortakların şahsi sorumluluğuna gidemezler. Ancak şahsi sorumluluğa dair bu sınırlandırma mutlak değildir (Ayrıntılı açıklamalar için bkz. Pulaşlı:2013, 289 ve 704; Bilgili, Demirkapı:2013, 64). Şirket tarafından ödenmeyen alacak, vergi ve sosyal sigorta mevzuatından doğan, dolayısıyla alacaklı kamu kurumu tarafından 6183 sayılı Amme Alacaklarının Tahsil Usulü Hakkında Kanun hükümlerine göre tahsil edilen bir kamu alacağı söz konusu olduğunda, şirket ortakları yönetici ya da salt ortak sıfatlarına bağlı şahsi sorumluluğu gündeme gelir.

Ortak ya da yöneticilerin şirketin kamu borçlarından şahsi sorumluluğu, ticaret hukukunun genel ilkelerine uygunluğu yönüyle tartışılabilirse de, bu hukuk politikasının konusudur, kanun koyucunun tercihidir. Buna karşın uygulamada kamu borçlarından şahsi sorumluluk konusunun kendisinden daha da sorunlu olan yönü, şirket ortaklık hisselerinin devri halinde kişisel sorumluluğun devralan açısından devir öncesi döneme de teşmil edilmesidir. Ortada kanundan doğan bir sorumluluk söz konusu olmakla, tarafların devri doğuran sözleşme ilişkisinde devir öncesi dönemden sorumluluğa ilişkin kararlaştırmaları, alacaklı kamu kurumu açısından bağlayıcı değildir. Bu konuda Danıştay 9. Dairesinin 24.05.2006 tarih E. 2004/4420 K. 2006/2114 sayılı kararında, 6183 sayılı Kanunun 35. maddesi tespit edildikten sonra "Diğer yandan 213 sayılı Vergi Usul Kanununun 'mükellef ve vergi sorumlusu' başlıklı 8. maddesinin 3. fıkrasında, vergi kanunlarıyla kabul edilen haller müstesna olmak üzere, mükellefiyete veya vergi sorumluluğuna müteallik özel mukavelelerin vergi dairelerini bağlamayacağı öngörülmüştür. Bu hükümlerin birlikte değerlendirilmesinden bir kamu borcu olan vergi borcundan yasa gereği doğan sorumluluğun, borçlu şirketin vergi borcunun doğduğu dönemde sahip olunan hisselerinin satışı yoluyla ortadan kaldırılamayacağı..." (http://legalbank.net/belge/d-9-dsi-e-2004-4420-k-2006-2114-t-24-05-2006-limited-sirketinkamu-borcu/291309/, 20.05.2017) tespitine dikkat çekmek isteriz.

Keza devir öncesi dönemde ayrıntılı bir ön inceleme yapılsa bile, sonrada şirketin kendisinin borç ödemede acze düşüp düşmeyeceği ve bu nedenle şahsi sorumluluğun doğup doğmayacağı da belli değildir. Sonuçta hisse devrinde devralanın, devir öncesi döneme ait kamu borçlarından şahsi sorumluluk ihtimalini bütünüyle ortadan kaldırması olanaklı değildir. Bu da uygulamada önemli çekişmelere neden olmaktadır.

Bu çalışmada, hisse devirlerinde eski ve yeni ortağın şirketin kamu borçlarından şahsi sorumluluğu konusu incelenecektir. Ancak bundan önce vergi ile sosyal güvenlik hukuku mevzuatında geçen şahsi sorumluluk halleri tespit edilecektir. Daha sonra da şahsi sorumluluk konusundaki bu istisnaların, ortaklık hisse devrinde uygulanışı konusu açıklanacaktır.

\section{MEVZUATIMIZDA ŞIRKET ORTAKLARININ KAMU BORÇLARINDAN ŞAHSI SORUMLULUĞU}

\subsection{Vergi Borçlarından Şahsi Sorumluluk}

21.07.1953 tarih ve 6183 sayılı Amme Alacaklarının Tahsil Usulü Hakkında Kanunun 3. maddesinde amme alacağı, Kanunun kapsamının düzenlendiği 1. ve 2. maddelerde geçen alacaklar şeklinde tanımlanmıştır. Kanunun 1. maddesinde "Devlete, vilayet hususi idarelerine ve belediyelere ait vergi, resim, harç, ceza tahkik ve takiplerine ait muhakeme masrafı, vergi cezası, para cezası gibi asli, gecikme zammı, faiz gibi fer'i amme alacakları ... hakkında bu kanun hükümleri tatbik olunur" kuralı vardır. Buna göre verginin kamu alacağı niteliğinde bulunduğu tartışmasızdır.

04.01.1961 tarih ve 213 sayılı Vergi Usul Kanunu, şirketlerin vergi borçlarından dolayı ortaklarına şahsi sorumluluk öngören düzenlemelerden biridir. Yasanın kanuni temsilcilerin ödevi başlıklı 10. maddesinde, tüzel kişilerle küçüklerin ve kısıtlıların, Vakıflar ve cemaatler gibi tüzel kişiliği olmayan teşekküllerin mükellef veya vergi sorumlusu olmaları halinde bunlara düşen vergi ödevlerinin kanuni temsilcileri tarafından yerine getirileceği tespit edilmiş; onların bu ödevleri yerine getirmemeleri yüzünden mükelleflerin veya vergi sorumlularının mal varlığından tamamen veya kısmen alınmayan vergi ve buna bağlı alacakların, kanuni ödevleri yerine getirmeyenlerin varlıklarından tahsil edileceği düzenlemiştir. Bu düzenleme tüzel kişiliği ister olsun isterse de olmasın, bir kanuni temsilci, başka deyişle yönetici tarafından idare edilen vergi mükelleflerini esas almaktadır.

Yine kanuni temsilcinin şahsi sorumluluğuna gidilebilmesinin ön şartı, verginin mükellefin kendisinden tahsil edilememiş olmasıdır (Silahşör:2016, 70, Gerçek:2005, 179). Vergi alacağının tahsili için önce mükellefin malvarlığına başvurulmalı ve bir sonuç elde edilememiş olmalıdır. Bu konudaki bir Danıştay kararında, haklı olarak şu açıklamalara yer verilmiştir: "Vergi Usul Kanunu kapsamındaki vergi ve buna bağlı alacaklarda limited şirket ortaklarının 6183 sayılı Yasanın 35'inci maddesine göre takibi gerekmekte olup, bir tüzel kişinin ortağının sorumlu tutularak, sözü edilen hüküm uyarınca takip edilebilmesi için kamu alacağının sorumlu sıfatıyla kendisinden tahsil edileceğinin ortağa duyurulmasından önce borcun tüzel kişiye usulüne uygun biçimde tebliğ edilmesi, uyuşmazlık yaratılmak suretiyle ya da uyuşmazlık yaratılmaksızın kesinleşmiş bulunmasına rağmen vadesinde ödenmemiş olması, bu nedenlerle tüzel kişinin 6183 sayılı Yasanın 54, 55 ve müteakip maddeleri uyarınca takip edilmesi ve bütün bunlara rağmen kamu alacağının tüzel kişinin mal varlığından tamamen veya kısmen tahsil edilememiş olması gerekir.

Davaya konu yapılan ödeme emrinde yer alan kamu alacağının gerçek borçlusu limited şirketin mal varlığından tahsil imkanı bulunmadığı neden gösterilerek davacı adına şirketteki payına göre ödeme emri düzenlendiği anlaşımakta ise de dosyada 
mevcut şirket tüzel kişiliği adına 27.2.2006 tarihinde düzenlenmiş ve ne şekilde tebliğ edildiği de anlaşılamayan ödeme emirlerinin, dava konusu ödeme emirleriyle aynı tarihli olduğu görülmüş ve dosyaya; şirketin daha önceki vergi borçları nedeniyle 2000-2005 yıllarında yapılan mal varlığı araştırmasına yönelik yazılar ile davacı adına takibe başlandıktan sonraki bir tarihli mal varlığı araştırma yazısı sunulmuştur.

Davacının ortak sıfatıyla sorumlu tutularak 6183 sayılı Yasanın 35. maddesi uyarınca takip edilebilmesi için dava konusu ödeme emirlerinin duyurulmasından önce, borcun şirket tüzel kişiliğine duyurulması ve tüzel kişiden takibine ilişkin yukarıda açıklanan koşulların gerçekleşip gerçekleşmediği saptandıktan sonra davanın sonuçlandırılması gerekirken, bu yönde bir inceleme yapılmaksızın, yazılı gerekçeyle verilen vergi mahkemesi kararında hukuka uygunluk bulunmamaktadır".

(Danıştay 3. Dairesi, 26.02.2009, E. 2007/5017 K. 2009/571, http://legalbank.net/belge/d-3-dsi-e-2007-5017-k-2009-571-t26-02-2009-limited-sirket-ortaklarinin-amme-alacaklarindan-sorumlul/654326/, 20.05.2017).

213 sayılı Vergi Usul Kanunundaki bu düzenleme ile hemen hemen aynı içerikte bir hüküm, 6183 sayılı Kanunun mükerrer 35. maddesinde bulunmaktadır. Bu maddeye göre, "Tüzel kişilerle küçüklerin ve kısıtıların, vakıflar ve cemaatler gibi tüzel kişiliği olmayan teşekküllerin mal varlı̆̆ından tamamen veya kısmen tahsil edilemeyen veya tahsil edilemeyeceği anlaşılan amme alacakları, kanuni temsilcilerin ve tüzel kişiliği olmayan teşekkülü idare edenlerin şahsi mal varlıklarından bu Kanun hükümlerine göre tahsil edilir". Buradaki sorumluluk, 6183 sayılı Kanunun aşağıda incelenecek 35. maddesinden farklı olarak tüm tüzel kişileri, bu arada limited şirketlerden başka anonim şirketleri de kapsamaktadır.

Şahsi sorumluluğa ilişkin Vergi Usul Kanunundaki hükme benzer bir düzenlemenin 6183 sayılı Kanunda ayrıca yinelenmesi ile amaç, sorumluluğun kapsamının vergi borçları dışında 6183 sayılı Kanun hükümlerine göre takip edilen tüm kamu alacaklarını içerir biçimde genişletmektir (Ay, Baran:2014, 61).

\subsection{Sosyal Sigorta Prim Borçlarından Şahsi Sorumluluk}

Sosyal Güvenlik Kurumunun sigorta prim alacaklarının kamu alacağı niteliği, 5510 sayılı Sosyal Sigortalar ve Genel Sağlık Sigortası Kanununda vurgulanmıştır. Kanunun 88. maddesinin 16. fıkrasına göre, "Kurumun süresi içinde ödenmeyen prim ve diğer alacaklarının tahsilinde, 6183 sayılı Amme Alacaklarının Tahsil Usûlü Hakkında Kanunun 51 inci, 102 nci ve 106 ncı maddeleri hariç, diğer maddeleri uygulanır. Kurum, 6183 sayılı Kanunun uygulanmasında Maliye Bakanlığı ile diğer kamu kurum ve kuruluşları ve mercilere verilen yetkileri kullanır" (5510 s. K. m. 88/16 ile ilgili ayrıntılı açıklamalar için bkz. Güzel, Okur, Caniklioğlu:2016, 286 vd.).

Bu açık hüküm nedeniyle sosyal sigorta primlerinin kamu alacağı niteliği açık olup, aynı Kanunun aynı maddesinde bu alacaklarla ilgili bir şahsi sorumluluk hükmü yer almaktadır. Hükme göre, "Kurumun sigorta primleri ve diğer alacakları haklı bir sebep olmaksızın bu Kanunda belirtilen sürelerde ödenmez ise, kamu idarelerinin tahakkuk ve tediye ile görevli kamu görevlileri, tüzel kişiliği haiz diğer işverenlerin şirket yönetim kurulu üyeleri de dahil olmak üzere üst düzeydeki yönetici veya yetkilileri ile kanuni temsilcileri Kuruma karşı işverenleri ile birlikte müştereken ve müteselsilen sorumludur". Burada şahsi sorumluluk açısından işverenin kamu ya da özel sektör olması arasında fark gözetilmiştir.

Şayet işveren 5018 sayılı Kamu Mali Yönetimi ve Kontrol Kanunu anlamında bir kamu kurum ya da kuruluşu ise, onlar adına sosyal sigorta primlerini tahakkuk ve tediye ile görevli personelinin bir şahsi sorumluluğu vardır. Burada geçen "tahakkuk ve tediye ile görevli personel", 5018 sayılı Kanundaki harcama yetkilisi ile gerçekleştirme görevlisi işlevlerini yerine getiren kamu görevlilerine karşılık gelmektedir.

Niteliği gereği kamu işverenliklerinde şirket ortaklığındaki işletme (kar-zarar) rizikosu gibi bir durum söz konusu değilse de, kamu görevlisinin şahsi sorumluluğunu gerektiren neden, Sosyal Güvenlik Kurumuna ödenmeyen sosyal sigorta priminin zaten işveren kurumun bütçesinde yer alıyor olmasıdır. İlke olarak işveren kurum adına sosyal sigorta primlerini tahakkuk ve tediye ile görevli personel yasal yükümlülüklerini gereğine uygun yerine getirse idi, primlerin ödenmemesi gibi bir durum söz konusu olmayacaktır. Dolayısıyla kamu işverenlerinin sosyal sigorta primlerinin ödenmemesinin, her halükarda tahakkuk ve ödeme ile görevli personelin kusurundan kaynaklandığı yolunda aksi ispatlanabilir bir karineden bahsedilmesi hatalı olmayacaktır.

Süresinde ödenmeyen sosyal sigorta primleri bakımından kamu kurumları dışında kalan, tüzel kişiliği haiz diğer işverenliklerde şahsen sorumlu olanların kapsamı daha da geniş tutulmuştur: (1) şirket yönetim kurulu üyeleri, (2) üst düzeydeki yönetici veya yetkilileri ve (3) kanuni temsilcileri. İşverenle birlikte müteselsilen sorumluluğu öngörülen bu üç grup dikkate alındığında, sosyal sigorta prim borçlarından şahsen sorumluluk konusunda şirkette ortak olup olmamanın esasa etkili bulunmadığı görülmektedir. Çünkü anonim şirketlerin yönetim kurulu üyeleri ve limited şirketlerin de müdürleri, şirket ortağı olabileceği gibi dışarından üçüncü kişiler de olabilecektir (Pulaşı:2013, 396 ve 773 ). Keza bir şirket işverenliğinde iş sözleşmesi ile çalışan genel müdür ya da finans müdürünün de, üst düzey yönetici veya yetkili olarak prim borçlarından şahsi sorumluluğu doğabilecektir.

Buna göre anonim şirket yönetim kurulu üyeleri dışında kalan üst düzey yöneticiler veya kanuni temsilcilerin şahsi sorumlulukları açısından ölçü, işverenliğin iş organizasyonunda sosyal sigorta primlerinin tahakkuk ile ödenmesinden olan sorumluluktur. Bu açıdan limited şirketlerde şirketin kanuni temsilcileri olarak müdürlerin yasal yetki ve sorumlulukları itibariyle şahsi sorumluluğun kapsamında kaldığı açıktır. Ancak şahsi sorumluluk içi her zaman yasal temsilci konumunda olmak gerekmez. Şirketin üst düzey yönetici veya yetkilileri, iş organizasyonundaki konumları ve yetkileri itibariyle sosyal sigorta işlemlerinden sorumlulukları kabul edilebiliyorsa, şahsi sorumluluğun da kabul edilmesi gerekir. 
Konuyla ilgili Yargıtay uygulaması incelendiğinde, "Yerleşmiş Yargıtay uygulamaları ile öğretide kabul edildiği üzere 'üst düzey yönetici' kavramından anlaşılan şirketin mali ve idari konularında tek başına emir ve tasarruf yetkesine sahip özel şekilde kendisine yetki verilen kişidir. Türk Ticaret Kanunu'nun 317. maddesine göre anonim şirketlerde şirketi yönetmek ve temsil etmek yönetim kuruluna aittir. Anonim şirkette primlerin ödenmesinde müteselsilen sorumlu üst yönetici ve yetkiliden söz edebilmek için primlerin tahakkuk ve ödenmesinde yetkili üst düzey yönetici olması, yönetim kurulu başkanı, başkan yardımcısı gibi unvan taşıması veya temsil ve ilzam yetkisine sahip yönetim kurulu üyesi olması gerekir" (Yarg.21.HD, 01.03.2011, E.2010/1187, K. 2011/1757, http://legalbank.net/belge/y-21-hd-e-2010-1187-k-2011-1757-t-01-03-2011-ustduzey-yoneticinin-prim-borclarindan-sorumlulugu/866707/, 20.05.2017).

\subsection{Limited Şirket Ortakları Hakkında Özel Düzenleme}

Bir sermaye şirketi olarak ortakların şahsi sorumluluğu bulunmayan limited şirketler hakkında 6183 sayılı Kanunda özel bir düzenleme bulunmaktadır. Kanunun limited ortaklıkların amme borçları başlıklı 35. maddesinde, ortakların şirket borçlarından şahsi sorumluluğu, 6183 sayılı Kanun kapsamında takip edilen tüm kamu alacakları, bu arada vergi, sosyal sigorta primleri kapsar biçimde düzenlemiştir. Hükme göre, "Limited şirket ortakları, şirketten tamamen veya kısmen tahsil edilemeyen veya tahsil edilemeyeceği anlaşılan amme alacağından sermaye hisseleri oranında doğrudan doğruya sorumlu olurlar ve bu Kanun hükümleri gereğince takibe tabi tutulurlar".

Bu hüküm kapsamında ortağın şahsi sorumluluğuna gidilebilmesinin ön şartı, kamu alacağının şirketten tahsil edilmek istendiği, bunun için yasal takip süreçleri işletildiği halde, bütünüyle ya da kısmen sonuç elde edilememiş olmasıdır (Biyan:2012, 99, Gerçek:2005, 175, Yücel:2012, 213): "Sözü edilen düzenlemeye göre, Vergi Usul Kanunu kapsamındaki vergi ve buna bağlı alacaklarda limited şirket ortaklarıın 6183 sayılı Yasanın 35'inci maddesine göre takibi gerekmekte olup, bir tüzel kişinin ortağının sorumlu tutularak, sözü edilen hüküm uyarınca takip edilebilmesi için kamu alacağının sorumlu sıfatıyla kendisinden tahsil edileceğinin ortağa duyurulmasından önce borcun tüzel kişiye usulüne uygun biçimde tebliğ edilmesi, uyuşmazlık yaratılmak suretiyle ya da uyuşmazılık yaratılmaksızın kesinleşmiş bulunmasına rağmen vadesinde ödenmemiş olması, bu nedenlerle tüzel kişinin 6183 sayılı Yasanın 54, 55 ve müteakip maddeleri uyarınca takip edilmesi ve bütün bunlara rağmen kamu alacağının tüzel kişinin mal varlığından tamamen veya kısmen tahsil edilememiş olması gerekir"(Danıştay 3. Dairesi, 26.02.2009, E. 2007/5017, K. 2009/571, http://legalbank.net/belge/d-3-dsi-e-2007-5017-k2009-571-t-26-02-2009-limited-sirket-ortaklarinin-amme-alacaklarindan-sorumlul/654326/, 20.05.2017).

Şahsi sorumluluğun işletilebilmesinin ön aşaması olarak şirket bakımından kamu alacağının kesinleşmiş ve şirketten tahsil edilemeyeceğinin açık olması hususu, dava şartı olarak mahkemece resen dikkate alınmaktadır (Yarg.17.HD, 02.07.2013, 7656/10498, http://legalbank.net/belge/y-17-hd-e-2013-7656-k-2013-10498-t-02-07-2013-limited-sirket-ortaklarininsirketten-tamamen-veya-kis/1407165/, 20.05.2017).

Düzenlemenin dikkati çeken bir başka yönü, ortağın şahsi sorumluluğunun sermaye pay oranı ile sınırlı olmasıdır (Gerçek:2005, 179, Budak, Er:2013, 80). Hükümde geçen "sermaye hisseleri oranında" ifadesiyle tahsil edilemeyen kamu alacağının ortağın ödediği sermaye tutarı ile mi sınırlı olduğu yoksa, toplam borcun ortalık pay oranına düşen kısmını mı kapsadığı sorgulanabilir. Hisse, bütünün belirli bir bölümünü ifade ettiğine göre, hisse oranı şirket bütünü içindeki payı gösterir.

Keza 35. maddede yapılan değişikliklerden bu husus teyit olunmaktadır. Hükmün ilk halinde ortakların "vazettikleri veya vaz'ını taahhüt eyledikleri sermaye miktarından" söz edildiği halde, maddede 22.07.1998 tarih ve 4369 sayılı Kanunun 21. maddesi ile yapılan değişiklik ile "amme alacağından sermaye hisseleri oranında" şeklinde bir değişikliğe gidilmiştir.

Buna göre, örneğin şirketin \%50 hissedarlığı karşılığında taahhüt edilen sermaye 50 TL ve şirketin ödenmeyen kamu borcu da 200 TL olsa, bu ortak ödediği 50 TL sermaye ile sınırlı değil, 200 TL borcun \%50 hisseye karşılık gelen 100 TL'sinden şahsen sorumludur. Bu husus Yargıtay 10. Hukuk Dairesinin 16.03.2006 tarih ve E. 2005/12534, K. 2006/2884 sayılı kararında şu şekilde vurgulanmıştır: "Davacının... işveren limited şirketin ortağı sıfatıyla, ödeme emrine konu kurum alacağından sorumluluğunun şirketteki sermaye hissesine göre belirlenmesi gerekirken, mahkemece; anılan maddenin değişiklikten önceki hükmünde öngörülen biçimde davacının şirkete koymayı taahhüt ettiği sermaye miktarı ile sınırlı biçimde sorumluluğunun kabulü ile yazılı şekilde hüküm kurulması usul ve yasaya aykırı olup, bozma nedenidir" (http://legalbank.net/belge/y-10-hd-e-2005-12534-k-2006-2884-t-16-03-2006-odenmeyen-sigorta-primlerintahsili/436583/, 20.05.2017).

\section{HISSE DEVRINDE ŞAHSI SORUMLULUĞUN KAPSAMI}

Yukarıda incelendiği üzere şirketlerin ödenmeyen kamu borçlarından ortaklarının şahsi sorumluluğu mevzuatımızda birden fazla yerde düzenlenmiştir. Ancak hisse devrinde devreden eski ve devralan yeni ortağın devir öncesinden şahsi sorumluluklarını ele alan tek düzenleme 6183 sayılı Kanunun 35. maddesinin 04.06.2008 tarih ve 5766 sayılı Kanunun 3. maddesi ile eklenen 2. ve 3. fıkralardır.

Buna göre, vergi ya da sosyal sigorta primi kamu alacağının borçlusu limited şirketten başka bir şirket ya da tüzel kişi olduğunda, 213 sayılı Kanunun 10. maddesinden, 5510 sayılı Kanununun 88. maddesinden ve 6183 sayılı Kanununun mükerrer 35. maddesinden doğan şahsi sorumluluk, devreden ve devralan taraflar açısından herkesin kendi döneminde doğan borçlarla sınırlıdır. Böyle bir ayrımın gerekçesi, 6183 sayılı Kanunun 35. maddesi dışındaki diğer düzenlemelerdeki şahsi sorumluluk kabulünün, kamu alacağının tüzel kişinin kendisinden ilgililerin yasal hak ve yükümlülükleri itibariyle 
kusurlu davranışları sonucunda alınamadığı varsayımına dayanmasıdır. Başka deyişle burada hukuktaki genel sorumluluğun kusura dayanması ilkesi gözetilmiştir (Ay, Baran:2014, 61, Biyan:2012, 100, Silahşör:2016, 68-69). Limited şirketlerle ilgili düzenlemede ise, sorumluluk ortağın şahsına değil şirketteki payına dayanmaktadır. Bu anlamda kişisel sorumluluğun kaynağı objektif bir durumdur (Ay, Baran:2014, 61).

\subsection{06.2008'den Önceki Dönem}

6183 sayılı Kanunun limited şirketlerin ödenmeyen kamu borçlarından ortakların şahsi sorumluluğunu düzenleyen 35 . maddesi 04.06.2008 tarih ve 5766 sayılı Kanun ile değiştirilene kadar, bir fıkradan oluşmaktaydı. Burada sadece şahsi sorumluluk, sorumluluğun doğuşu ve kapsamı bakımından şatlara yer verilmiştir. Bu dönemdeki uygulamada, devralan hissedarın devir öncesi dönemde doğmuş borçlardan sorumluluğu ve devreden hissedarın devir tarihi itibariyle doğmuş borçlardan devirden sonraki dönemde sorumluluğu açık değildi.

Danıştay 7. Dairesinin bu konudaki 02.12.1999 tarih ve E. 1997/4847 K. 1999/4008 sayılı kararında, “... vergi borcunun, şirket ortağı olan davacıdan şirketteki hissesine isabet eden kısmının tahsili amacıyla, 213 sayılı Kanunun 10'uncu maddesine göre değil, 6183 sayılı Kanunun 35'inci maddesine göre ödeme emri düzenlendiği; ödeme emrinin tanzim ve tebliğ olunduğu tarihten önce de davacının ortaklık payını diğer ortağa devrederek, ortaklıktan ayrıldığı anlaşılmaktadır. 6183 sayılı Kanunun 35'inci maddesinde, limited şirketin tahsil olanağı kalmayan kamu borçlarından dolayı ortaklar için öngörülen sorumluluk, ortak sıfatına ve ortaklık payına bağlı bir sorumluluktur. Bir başka anlatımla ortaklık payı kimde ise, sorumlu kişi odur" görüşü açıklanmıştır.

Ancak bu görüş istisna nitelikte olup, genel uygulama aksine hissesini devredenin devir tarihine kadar olan ve devralanın da devir tarihine kadar olan dönemden münhasıran sorumluluğu şeklindedir. Önceki dönemde verilmiş Danıştay Vergi Daireleri Kurulu kararında şu ifadelere yer verilmiştir: "...şirketten tahsiline olanak bulunmayan kamu alacaklarının ödenmesinden doğrudan doğruya ve payları oranında sorumlu tutan kural karşısında, tahsili gereken kamu alacağını yaratan vergilendirmenin ait olduğu dönemde şirketin paylarına sahip ortakların, bu dönemden sonra paylarını devretmiş olsalar da ortaklık sıfatının sürdüğü dönemlere ilişkin şirketin kamu borçlarından sorumluluklarının kalkması söz konusu edilemez..." (19.06.2009, E. 2008/645, K. 2009/306, http://legalbank.net/belge/d-vergi-dava-daireleri-kurulu-e-2008-645-k-2009-306-t19-06-2009-odeme-emrine-konu-vergi-borcunun-ai/1393049/, 20.05.2017). Benzer şekilde Danıştay 4. Dairesi bir kararında 6183 sayılı Kanunun 35. maddesini tespit ettikten sonra, "ödeme emri ile takip edilen kamu alacaklarından, hangi vergilendirme dönemine ilişkin olarak tahakkuk etmiş ise, şirket hakkındaki kanuni takip yolları tüketilmek koşuluyla bunların ödenmemesinden de, yine aynı dönemde ortak olan kişinin sadece ortak olduğu dönemlerle sınırlı olarak sorumlu olacağı sonucuna ulaşılmaktadır" görüşüne yer vermiştir (09.08.2009, E. 2008/5380, K. 2009/1913, http://legalbank.net/belge/d-4-d-e-2008-5380-k-2009-1913-t-13-04-2009-sirket-ortaklarinin-kamu-borclarindansorumlulugu/586624/, 20.05.2017).

Yine Danıştay 3. Hukuk Dairesinin 10.06.2015 tarih ve E. 2012/4863 K. 2014/4670 sayılı kararında, "6183 sayılı Kanunun 35'inci maddesinden doğan ve limited şirket ortaklarını, şirketten tahsiline olanak bulunmayan kamu alacaklarının ödenmesinden doğrudan doğruya ve payları oranında sorumlu tutan söz konusu kural karşısında, tahsili gereken kamu alacağının ait olduğu dönemde ortaklık sıfatını sürdüren şirket paylarına sahip ortakların söz konusu dönemlere ilişkin şirketin kamu borçlarından kaynaklanan sorumlulukları bulunduğu, paylarını devrettikten sonraki dönemlere ilişkin şirket borçlarından ise sorumlu tutulamayacağı tartışmasızdır... Bu nedenle, kamu alacağından kaynaklanan sorumluğu ortak olunmakla başlayacağından ve ortak olmadığı döneme ilişkin ödeme emrine konu şirket borcunun tahsili amacıyla davacı adına bu sıfatla düzenlenen ödeme emrinde hukuka uyarlık bulunmadığından..." tespiti vardır (http://legalbank.net/belge/d-3-d-e-2012-4863-k-2015-4670-t-10-06-2015-ortagi-oldugu-sirketinin-2000-yili-gecici-vergiborcuna-i/1501631/,20.05.2017).

Buna göre hissesini devredenin devir tarihinden sonra devir öncesi kamu borçlarından sorumluluğu açık olup, devralanın devir öncesi dönem borçlarından sorumluluğu bulunmamaktaydı.

\subsection{06.2008'den Sonraki Dönem}

6183 sayılı Kanunun 35. maddesine 04.06.2008 tarih ve 5766 sayılı Kanunun 3. maddesi ile eklenen iki fıkra ile devralanın devir öncesi dönem prim borçlarından devreden ile birlikte müteselsilen sorumluluğu kabul edilmiştir. Bu değişiklik ile şirket ortaklığından doğan şahsi sorumluluk, ortaklık sıfatının varlığı ile sınırlandırımamış olmakta, adeta ortaklık hissesinin kendisine mündemiç hale getirilmektedir.

Yeni düzenlemeye göre, "Ortağın şirketteki sermaye payını devretmesi halinde, payı devreden ve devralan şahıslar devir öncesine ait amme alacaklarının ödenmesinden birinci fıkra hükmüne göre müteselsilen sorumlu tutulur. Amme alacağının doğduğu ve ödenmesi gerektiği zamanlarda pay sahiplerinin farklı şahıslar olmaları halinde bu şahıslar, amme alacağının ödenmesinden birinci fıkra hükmüne göre müteselsilen sorumlu tutulur".

Bu yeni düzenleme ile limited şirket ortaklarının kamu borçlarından şahsi sorumluluğunun kapsamıyla ilgili, limited şirket ortakları dışındaki tüzel kişilerle ilgili 213 sayılı Kanunun 10. maddesi, 5510 sayılı Kanunun 88. maddesi ve 6813 sayılı Kanunun mükerrer 35. maddesindeki sorumluluklarla ilgili değişen bir durum söz konusu değildir. Bu hükümlerde geçen şahsi sorumlulukla ilgili herkesin kendi dönemiyle sınırlı sorumlu olması ilkesi aynen geçerlidir (Silahşör:2016,74). Buna göre ilgili hükümlerde geçen kanuni temsilcilik görevi, şirket ortaklığının ve buna bağlı yönetim kurulu üyeliğinin hisse devri 
üzerine sona erdiği durumda bile, tüzel kişi örneğin bir anonim şirket olduğunda, devreden eski ortak devir tarihine kadar olan dönem için zamanaşımı süresi ile ve devralan yeni ortak da devir tarihinden itibaren şahsen sorumlu olmaktadır.

Ancak belirtmek gerekir ki, 6183 sayılı Kanunun 35. maddesine yukarıdaki fıkraları ekleyen 5766 sayılı Kanunun 4. maddesi ile de, 6183 sayılı Kanunun kanun temsilcilerin sorumluluğu başlıklı mükerrer 35. maddesine "Amme alacağının doğduğu ve ödenmesi gerektiği zamanlarda kanuni temsilci veya teşekkülü idare edenlerin farklı şahıslar olmaları halinde bu şahıslar, amme alacağının ödenmesinden müteselsilen sorumlu tutulur" hükmü eklenmiştir. Bu surette tüm tüzel kişileri kapsar biçimde ve ortaklık hisse devrinden bağımsız olarak sırf kanuni temsilcilik sıfatına bağı olarak kamu borçlarından şahsi sorumluluk temsilcilik görevinin sona erdiği tarih kadar sınırlı iken, temsilcilik görevi sona ermeden önceki bir tarihte doğduğu halde ödeme tarihinin yeni temsilcinin göreve başladığı dönemde olan kamu borçlarından her ikisinin birlikte sorumluluğu öngörülerek şahsi sorumluluğun kapsamı genişletilmiş olmaktadır. Ancak bu hükmün Anayasa Mahkemesi tarafından 19.03.2015 tarih ve E. 2014/144 ve K. 2015/29 sayılı karar ile iptal edildiğini belirtmek isteriz.

İkinci olarak, yeni hükümle limited şirketin hisse devreden ortağının hukuki durumunda eskiye göre bir değişiklik bulunmamaktadır. Değişiklik devralan yeni ortağın devir öncesi dönemde doğmuş ve şirketten tahsil edilememiş kamu alacaklarının devreden ortak yanında müteselsilen devralan ortaktan da tahsil imkanı getirilmiş olması yönüyledir. Bu şekilde limited şirketin kamu borçlarında ortağın şahsi malvarlığı ile sorumluluğu, şahsa bağlı olmaktan çıkarılarak ortaklık hissesine bağlanmış olmaktadır.

Yeni düzenlemenin dikkati çeken bir başka yönü, yeni 3. fıkrada hissesini devreden ortağın sorumluluğunun kapsamının dönemsel açıdan kısmen genişletilmiş olmasıdır. Hemen yukarıda tespit edildiği üzere hissesini devreden ortak, devir tarihine kadar olan kamu borçlarından şahsen sorumlu olmaktadır. Ancak bu yeni fıkrada, devredenin sorumluluğu tarih olarak değil ancak daha tahakkuk aşamasındaki kamu borçlarına da teşmil edilerek genişletilmiştir. Buna göre kamu alacağının doğduğu tarih ile ödenmesi gerektiği tarih arasındaki dönemde hisse devri gerçekleştiğinde, başka deyişle hisse devrinden önce tahakkuk etmiş ancak devir tarihi itibariyle ödeme günü gelmemiş kamu borcundan, devreden ortak devir tarihinden sonra da şahsen sorumlu olacaktır.

\subsection{Devralan Yeni Ortağın Devir Öncesinden Sorumluluğunun Kanun Değişikliğinden Önceki}

\section{Kamu Borçlarına da Uygulanması}

Belirtildiği üzere limited şirketlerde hisse devrinde devralan yeni ortağın devir öncesi kamu borçlarından şahsi sorumluluğu ilk olarak 2008 yılındaki değişiklik ile uygulanmaya başlanmıştır. Ancak kanun koyucu bu yeni düzenleme ile daha önceden limited şirketin kendisinden ya da hissesini devreden ortağın şahsi malvarlığından tahsil edilememiş kamu alacaklarının da tahsil edilebilmesi adına, 04.06.2008 tarih ve 5766 sayılı Kanunun ile 6183 sayılı Kanunun 35. maddesine ilgili iki fıkra eklendikten başka, 5766 sayılı Kanunun geçici 1. maddesinde, "Bu Kanunla 6183 sayılı Kanunda yapılan değişiklikler ve eklenen hükümler, hükümlerin yürürlüğe girdiği tarih itibarıyla tahsil edilmemiş bulunan amme alacakları hakkında da uygulanır" hükmüne yer verilmiştir (Yücel:2012, 215).

Bu geçici madde ile hisse devrinin 04.06.2008 tarihinden önce olduğu ve dolayısıyla hisseyi devralanın sorumlu olmadığı devir tarihi öncesine ait kamu borçlarından, yeni hükümle geçmişe etkili olarak sorumluluk doğmuş olmaktadır. Bu surette hukukta istisna olan bir durum, kanunun geçmişe etkili yürürlüğü söz konusudur (Budak, Er:2013, 89 vd.). Bu geçici hüküm isabetle Anayasa Mahkemesine taşınmış ve yüksek mahkeme maddenin iptaline karar vermiştir. Anayasa Mahkemesi 28.04.2011 tarih ve E. 2009/39 K. 2011/68 sayılı kararında (RG. 15.10.2011, 28085), 5766 sayılı Kanun'un 3. maddesiyle limited şirket ortaklarının amme alacakları ile ilgili sorumlulukları genişlettiği ve şirket hisselerini devreden ve devralan ortaklara; 4. maddesi ile de kanuni temsilci veya teşekkülü idare edenlere amme alacağının ödenmesinde müteselsilen sorumluluk esası getirildiği ve Vergi Usul Kanunu kapsamındaki amme alacaklarının takibinin bu şahıslar hakkında 6183 sayılı Kanun'un uygulanmasına engel oluşturmayacağı düzenlemelerini özetledikten sonra, Anayasanın hukuk devleti ilkesine vurgu yapmıştır:

“Anayasa'nın 2. maddesinde yer alan hukuk devleti, insan haklarına dayanan, bu hak ve özgürlükleri koruyup güçlendiren, eylem ve işlemleri hukuka uygun olan, her alanda adaletli bir hukuk düzeni kurup bunu geliştirerek sürdüren, hukuk güvenliğini gerçekleştiren, Anayasa'ya aykırı durum ve tutumlardan kaçınan, hukuku tüm devlet organlarına egemen kılan, yargı denetimine açık olan devlettir. Hukuk devletinin sağlamakla yükümlü olduğu hukuk güvenliği ilkesi, hukuk normlarının öngörülebilir olmasını, bireylerin tüm eylem ve işlemlerinde devlete güven duyabilmesini, devletin de yasal düzenlemelerde bu güven duygusunu zedeleyici yöntemlerden kaçınmasını gerekli kılan ve temel hak güvencelerinde korunan ortak değerdir. Kural olarak hukuk güvenliği yasaların geriye yürütülmemesini zorunlu kılar. Bu nedenle "Kanunların geriye yürümezliği ilkesi" uyarınca yasalar yürürlüğe girdikleri tarihten sonraki hukuki durumlara uygulanabileceklerinden, sonradan çıkan bir kanun yürürlüğe girdiği tarihten önceki olaylara uygulanmaz.

Kamu alacaklarının tahsilinde, geriye yürümenin söz konusu olup olmadığının saptanabilmesi için alacağı doğuran olayın ne zaman meydana geldiğinin tespiti gerekir. Genel olarak kamu alacağı alacak konusu olayın meydana gelmesi veya hukuki durumun oluşması ile doğmaktadır. Dolayısıyla kamu alacağını doğuran olayın meydana geldiği veya hukuki durumun oluştuğu tarihte yürürlükte olan kanunun bu alacak için uygulanması gerekir.

İtiraz konusu geçici 1. maddeyle 5766 sayılı Kanun'la 6183 sayılı Kanunda yapılan değişiklikler ve eklenen hükümlerin Kanun'un yürürlüğe girdiği tarihte henüz tahsil edilmemiş, ancak daha önceki bir dönemde doğmuş ve ödenmesi gereken 
hale gelmiş kamu alacaklarına da uygulanması öngörülmek suretiyle Kanun hükümleri geriye yürütülmüş olmaktadır. Buna göre, amme alacağının sorumluluğunun tespitinde alacağı doğuran olayın gerçekleştiği zaman değil, Kanunun yürürlük tarihi itibariyle borcun halen tahsil edilmemiş olması esas alınmıştır. Kamu hizmetlerinin yürütülmesinde gerekli kaynağın elde edilmesi adına vergi ve diğer kamu alacaklarının takip ve tahsili için hukuki düzenlemeler ve ayrıcalıklı yetkilerle kolaylık ve hızlılık sağlanmasının doğal olduğu kabul edilmekle birlikte bu konuda bireylerin hakları ve hukukun genel ilkelerinin de göz önünde bulundurulması hukuk devletinin bir gereğidir.

Kanunun değişmeden önceki hükümlerine göre şirket ortağı olan veya hisse devri yolu ile ortaklığı bırakan şahıslar ile kanuni temsilcilerin faaliyetlerini ve konumlarını o tarihte yürürlükte olan kurallara göre sahip oldukları ve üstlendikleri sorumluluk çerçevesinde belirlemeleri doğaldır. Bu şahıslardan sonraki yıllarda getirilecek sorumluluğa göre konumlarını belirlemeleri ve ticari faaliyetlerini sürdürmeleri beklenemez.

Düzenlemeden beklenen kamu yararının, kamu alacaklarında ilgililerinin sorumluluklarını arttırarak ve müteselsil sorumluluk getirerek daha hızlı ve daha yüksek oranda tahsilâtın sağlanması olduğu anlaşılmaktadır. Buna karşı bireylerin, 5766 sayılı Kanunun yürürlük tarihinden önce doğmuş ve ödenmesi gereken kamu alacağından sorumlu oldukları dönemde öngörülmeyen sorumluluklar ile yükümlü tutulmaları, diğer bir anlatımla geçmişe yönelik sorumluluklarının arttırıması bireylerin hukuka olan güven duygusunu zedeler ve hukuk güvenliği ilkesi ile bağdaşmaz.

5766 sayılı Kanun'da esas olarak bir kamu alacağı ile ilgili bireylerin sorumluluklarını arttıran ve müteselsil sorumluluk getiren düzenlemelerin, Kanunun geçici 1. maddesi ile yürürlük tarihi itibari ile tahsil edilmemiş alacaklara da uygulanması hukuk kurallarının geriye yürütülmesi anlamına gelmekte ve Anayasada yer alan hukuk devleti kapsamındaki hukuk güvenliği ilkesi ile bağdaşmamaktadır".

\section{SONUC}

Mevzuatımızda yer alan kamu borçlarından şahsi sorumluluk öngören 6183 sayılı Kanunun 35. maddesi dışındaki tüm düzenlemeler, herkesin kendi döneminden sorumlu olması ilkesine dayanmaktadır. Bu kapsamda hisse devrine bağlı bir şahsi sorumluluk ortadan kalktığında, devreden devir tarihine kadar ve devralan da devirden itibaren olan kamu borçlarından sorumlu olmaktadır. Buna karşın bu esas 6183 sayılı Kanunun limited şirket ortaklarının kamu borçlarından şahsi sorumluluğunu düzenleyen 35. maddesine 2008 yılında 5766 sayılı Kanun ile eklenen iki yeni fıkra ile hisse devrinde devir öncesi döneme ait borçlardan devreden ve devralan ortağın müteselsilen sorumlu olmaları öngörülmüştür. Uygulamada kanundan doğan şahsi sorumluluğu dolanmak amacıyla muvazaalı hisse devirlerinin önlemek için getirilen yeni hüküm, şahsi sorumluluğu ortaklık sıfatına değil bizzat şirket hissesinin kendisine bağlamış olmaktadır, isabetli olduğu söylenebilir.

Ancak 5766 sayılı değişiklik Kanununun geçici 1. maddesi ile 6183 sayılı Kanunun 35. maddesinin yeni halinin, Kanun'un yürürlüğe girdiği tarihte henüz tahsil edilmemiş, ancak daha önceki bir dönemde doğmuş ve ödenmesi gereken hale gelmiş kamu alacaklarına da uygulanması öngörülmek suretiyle Kanun hükümleri geriye yürütülmüştür. Bu hükmün Anayasa Mahkemesi tarafından 2011 yılında iptal edilmesi, hukuk devleti ilkesi nedeniyle isabeti tartışmasızdır.

\section{KAYNAKÇA}

Ay, H., Baran, T. (2014), “Kamu Alacaklarının Korunma Yöntemleri ve Bir Değerlendirme”, Sosyoekonomi Dergisi, 2014/1, s.45-68.

Bilgili, F, Demirkapı, E. (2013), Şirketler Hukuku, 9. Bası, Bursa.

Biyan, Ö. (2012), "6102 Sayılı Türk Ticaret Kanununda Tek Ortaklı Şirket: Zorunlu Bazı Düzenlemelerin Vergi Hukukunda Yarattığı Eksiklik", Mali Çözüm Dergisi, 2012/Temmuz-Ağustos, s.91-110.

Budak, T.; Er, S. (2013), "Limited Şirket Ortaklarının Kamu Alacağına İlişkin Sorumluluklarının Değerlendirilmesi”, İnönü Üniversitesi Hukuk Fakültesi Dergisi, Cilt: 4, 2013/2, 75-104.

Gerçek, A.(2005), "Türk Vergi Hukukunda Vergi Sorumlusu, Sorumluluk Halleri Ve Türlerinin İncelenmesi”, Ankara Üniversitesi, Hukuk Fakültesi Dergisi, 2005/3, Cilt 54, s. 157-193.

Güzel, A., Okur, A., Caniklioğlu, N. (2016), Sosyal Güvenlik Hukuku, Yenilenmiş 16. Bası, İstanbul.

Pulaşlı, H. (2013), Şirketler Hukuku Genel Esaslar, Güncellenmiş 2. Baskı, Ankara.

Silahşör, M. (2016), “Anonim Şirket Yönetim Kurulu Üyelerinin Kamu Alacağı Sorumluluğu”, Ticaret ve Fikri Mülkiyet Hukuku Dergisi, 2016/1, s.67-80.

Yücel, M. (2012), “Vergi Usul Kanunu Ve Amme Alacaklarının Tahsil Usulü Hakkında Kanun Hükümlerine Göre Anonim Ve Limited Şirket Kanuni Temsilcileri Ve Sorumlulukları”, Mali Çözüm Dergisi, 2012/Temmuz-Ağustos, s.205-217. 